\title{
Molecular Marker Validation for Bacterial Leaf Blight Resistant Genes Xa21 and Xa4 in Ld 99-12- 38 / IRBB 60 Genetic Background
}

\author{
W.D.P Weerasinghe*, Kapila Siri Udawela ${ }^{1}$, U. Heiyantuduwa ${ }^{2}$ \\ and H.A.M. Wickramasinghe ${ }^{2}$
}

Postgraduate Institute of Agriculture

University of Peradeniya

Peradeniya,Sri Lanka.

\begin{abstract}
Bacterial leaf blight (BLB) disease is an emerging issue in rice cultivation of Sri Lanka. Xanthomonas oryzae $p v$. oryzae is causal organism. There is no chemical control method practice in the world to control the disease. Use of resistance varieties is most appropriate mode of control. Bacterial blight resistance Xa21 and Xa4 are dominant genes responsible for durable resistance of rice varieties for the disease. The advanced rice line, Ld 99-12-38 is farmer demanding, non lodging type, high yielding rice line and is susceptible to BLB. Therefore, an attempt was taken to improve it resistant to BLB through markerassisted backcross breeding (MAB) by crossing rice line with resistant variety IRBB60, and advanced plants up to $\mathrm{BC}_{3} \mathrm{~F}_{2}$ level. At the beginning selected two molecular markers namely pTA248 (Xa21) and PM1+MP2 (Xa4) were tested for their polymorphism with parental materials. To identify BLB resistance Xa21 and Xa4 alleles, markers were validated in thirty five $B C_{3} F_{2}$ progenies derived from a cross between Ld 99-1238/IRBB60. As the results selected two molecular markers were polymorphic with parental materials with the expected fragment sizes. Out of the tested 35 progenies, eight were confirmed with possessing both Xa21 and Xa4 with resistant to the disease, twenty one lines carried only the resistant allele Xa4. A paired t- test revealed that there is a significant difference in the resistance level exerted by progeny carrying resistance alleles of two genes than with one $(p=0.0064)$. In addition, six progeny lines were heterozygote for Xa4 locus; one progeny line was heterozygous at both loci. No lines were identified carrying only the Xa21. Therefore it can be concluded that resistant genes Xa4 and Xa21 has been pyramided to rice lines derived from cross between $L d$ 99-12-38/IRBB60 in $B C_{3} F_{2}$ progenies with similar morphological characters of $L d$ 99-12-38 to withstand BLB. The rice line Ld 99-12-38 does not carry any resistance genes regarding BLB and IRBB 60 consist of Xa21 and Xa4 alleles. The selected markers pTA248 and MP1+MP2 can be recommended to in marker-assisted selection of Xa21 and Xa4 genes in crosses involving the tested genetic background.
\end{abstract}

Key words: bacterial leaf blight, marker-assisted selection, rice, Xa21, Xa4

\section{INTRODUCTION}

Rice is the most important and most widely consumed staple food crop in the world. Demand for rice is steadily increasing, as the number of rice consumers is increasing, specially in developing countries (Khush and Jena, 2009). Though rice is world's most important food crop, there are many limiting factors for rice cultivation, such as socio economic, soil and land factors, water supply, availability of good clean and healthy seeds, weeds, pests and diseases, and other biological agents such as rats, birds etc. Rice blast and $\mathrm{BLB}$ are the major devastating diseases that limit rice yield significantly (Ou, 1985; Mew et al., 1993). Bacterial Leaf Blight (BLB) is caused by bacterial pathogen called Xanthomonas oryzae pv. oryzae and is one of the devastating diseases of rice, causing yield losses ranging from 74 to $81 \%$ (Srinivasan and Gnanamanickam,2005). There is no chemical control method practiced in the world to control BLB. Therefore development of resistant varieties is the most appropriate solution to the problem. Development of broad spectrum durable resistance through gene pyramiding for biotic stress resistance can be accelerated through the process of marker assisted selection (MAS) (Joshi and Nayak, 2010). So far, 40 BLB resistance genes have been reported (Khan, Naeem \& Iqbal, 2014).

Ld 99-12-38 is a farmer demanding, 31/2 month age group high yielding rice line. It is resistant to lodging, brown plant hopper and rice blast. This line was included in the national coordinated rice variety testing

\footnotetext{
Rice Research and Development Institute, Batalagoda, Sri Lanka.

2 Department of Agricultural Biology, Faculty of Agriculture, University of Peradeniya, Peradeniya, Sri Lanka.

* Corresponding author: deepika.weerasinghe@yahoo.com
} 
(NCRVT), variety adaptability testing (VAT) and large scale variety adaptability testing (LSVAT) under different agro ecological zones of Sri Lanka and performed well. However, was not released as a variety due to its susceptibility to BLB. Recently, it was found that this line is tolerant to drought (Wasala et al, 2015). Hence, its importance as a potential germplasm for the development of an elite variety has greatly increased. Therefore, backcross breeding procedure with marker-assisted selection (MAS) is suitable for improving line further with the available BLB resistant variety IRBB 60, containing Xa4, xa5, xa13 and Xa21 resistance genes (Huang et al., 1997). Therefore the objectives of this research is phenotypically assess the disease response of IRBB60,Ld 99-12-38, $\mathrm{BC}_{1} \mathrm{~F}_{1}, \mathrm{BC}_{2} \mathrm{~F}_{1}$ and $\mathrm{BC}_{3} \mathrm{~F}_{2}$ progenies of a cross between Ld 99-12-38/IRBB 60 , to validate the use of markers $p T A 248$ and $M P 1+M P 2$ for the presence of Xa21 and Xa4 in IRBB 60, Ld 99-12-38 and $\mathrm{BC}_{3} \mathrm{~F}_{2}$ progenies of a cross between Ld99-12-38/IRBB 60, and to develop an advanced breeding lines pyramided with resistant alleles of Xa21 and $\mathrm{Xa} 4$ confirming resistant to BLB through MAB.

\section{METHODOLOGY}

A BLB susceptible Ld 99-12-38 rice line was used as the recipient parent and BLB resistant IRBB 60 variety was used as donor parent. Twenty one days old seedlings of parents were transplanted in the field, with one plant per hill maintaining a spacing of $15 \times 20 \mathrm{~cm}$. All the cultural practices were done as the Department $t$ of Agriculture recommendations. At the flowering stage hybridization was carried out by adopting a hot water emasculation method as described by (Garceia.,Zaguirre, and Carreres, 2008). The resulted $F_{1}$ seeds were collected. Those seeds were established in a nursery and transplanted in field after 21 days along with parental lines. At late booting stage plants were inoculated with BLB inoculum collected from the BLB affected leaves in the field. Innoculum was prepared by cutting disease affected leaves into small pieces and suspended into distilled water about $1 / 2$ hour. The inoculums density was adjusted to $10^{8} \mathrm{CFU} / \mathrm{ml}(\mathrm{OU}$, 1985 ) and the plants were inoculated by clipping tips of 5-10 fully opened leaves as described by Kauffman et al., 1973. Disease reaction was scored two weeks after inoculation, the lesion length of upper most five leaves were measured $(\mathrm{cm})$ using a ruler. At the same time, length of five none destructive corresponding leaves were also measured and diseased leaf area percentage was calculated based on the lesion length and the length of the whole leaf. Plants having lesion length of less than $5 \mathrm{~cm}$ were considered as resistant (SES for rice IRRI, 2014). The selected resistance plants were back crossed with recipient parent Ld 99-12-38 and $\mathrm{BC}_{1} \mathrm{~F}_{1}$ was obtained. Following the same procedure $\mathrm{BC}_{2} \mathrm{~F}_{1}, \mathrm{BC}_{3} \mathrm{~F}_{1}$ were developed. Finally $\mathrm{BC}_{3} \mathrm{~F}_{1}$ population was allowed to selfing and $\mathrm{BC}_{3} \mathrm{~F}_{2}$ was obtained. The selected resistant plants in $\mathrm{BC}_{3} \mathrm{~F}_{2}$ similar characters with recipient parent were subjected for MAS to confirm the presence of BLB resistance Xa4 and Xa21 alleles.

\section{DNA Extraction and PCR Amplification}

DNA was extracted using two weeks old fresh leaf samples collected from nursery with C-TAB extraction method with few modifications. PCR was carried out and polymorphism was tested for parental lines against selected markers. The PCR was carried out for both markers with $15 \mu \mathrm{l}$ reaction volumes, with 5 pico moles of each forward and reverse primers, 1x PCR master mix (GoTaq Green Master Mix) and 150ng of each genomic DNA sample. PCR conditions for $p T A 248$ as, initial denaturation at $94^{\circ} \mathrm{C}$ for 5 minutes, followed by 35 cycles of denaturation $94^{0} \mathrm{C}$ for 1 minute, $59.1^{\circ} \mathrm{C}$ for 1 minute annealing and extension $72^{\circ} \mathrm{C}$ for 2 minutes. Final extension was $72^{\circ} \mathrm{C}$ for 5 minutes, and PCR conditions for $M P 1+M P 2$ was initial denaturation at $95^{\circ} \mathrm{C}$ for 4 minutes, and 35 cycles of denaturation $95^{\circ} \mathrm{C}$ for 30 seconds, annealing $56^{\circ} \mathrm{C}$ for 30 seconds and extension $72^{\circ} \mathrm{C}$ for 1 minute. Final extension was $72^{\circ} \mathrm{C}$ for 10 minutes. Marker polymorphism was visualized in a 3\% agarose gel electrophoresis assayed for two hours at gel electrophoresis and post stained with ethidium bromide.

\section{RESULTS AND DISCUSSION}

Bacterial leaf blight is caused by the plant pathogenic bacteria Xanthomonas oryzae pv. oryzae, and is one of the devastating diseases of rice causing yield losses ranging from $74-81 \%$ (Srinivasan and Gnanamanickam, 2005). When plants are infected at booting stage it results poor quality grains with a high proportion of broken kernels. Breeding and development of resistant varieties carrying major resistance alleles have been the most effective and economical strategy to control BLB with a minimal adverse effect on the environment (Huang et al. 1997; Jena and Mackill, 2008; Singh et al. 2001). 
Host plant resistance has been considered as the most economical and eco-friendly strategy for management of biotic stresses (Hulbert et al., 2001). For BLB there is no effective chemical control method practiced, hence, the only durable strategy is to grow resistant varieties. There are many BLB resistant germplasm available in the world, carrying multiple resistance alleles to the disease. So far 40 genes have been identified with alleles contributing to resistance against BLB (Khan, Naeem, \& Iqbal, 2014). However, in Sri Lankan rice varieties an assessment has not been carried out so far. In this investigation, the resistant germplasm IRBB 60 carrying the resistance dominant alleles of Xa4 and Xa21 (Huang et al., 1997) were successfully pyramided to the backcross progeny of IRBB 60/Ld 99-12-38.

The gene Xa21 conveys broad spectrum resistance against BLB, and through wide hybridization Xa21 was transferred from the wild species Oryza logistaminata to the susceptible rice cultivar IR 24, generating the near isogenic line IRBB 21 (Ikeda et al., 1990; Kush et al., 1990). When tested for disease resistance spectrum, IRBB 21 conferred a high level of resistance to many diverse Xoo strains from India and the Philippines (Kush et al., 1990). The resistant parent IRBB 60 is a descendent of IRBB 21. The BLB resistance allele $\mathrm{Xa} 4$ identified by Petpisit et al., 1977, is one of the widely exploited resistance genes in many rice breeding programs, and it confers durable resistance at all stages of plant growth in many commercial rice varieties (Mew et al., 1992; Sun et al., 2003).

The advanced breeding line Ld 99-12-38 is a high yielding line with good plant architecture. It is resistant to blast disease, and it is drought tolerant. Though it is important as a valuable germplasm with a potential of has been developed as a variety, its release is hindered as a result of its susceptibility to the BLB. Given its prospectus as a high yielding variety with multiple resistances against major biotic and abiotic stresses.

Based on the data collected over four consecutive seasons, it was confirmed that the Ld 99-12-38 advance line was susceptible to BLB, and the IRBB 60 variety was resistant, at the late booting stage to X.oryzae pv. oryzae. The disease development was observed as early as fourteen days after inoculation in both Ld 99-1238 and IRBB 60 rice varieties (Fig. 1).
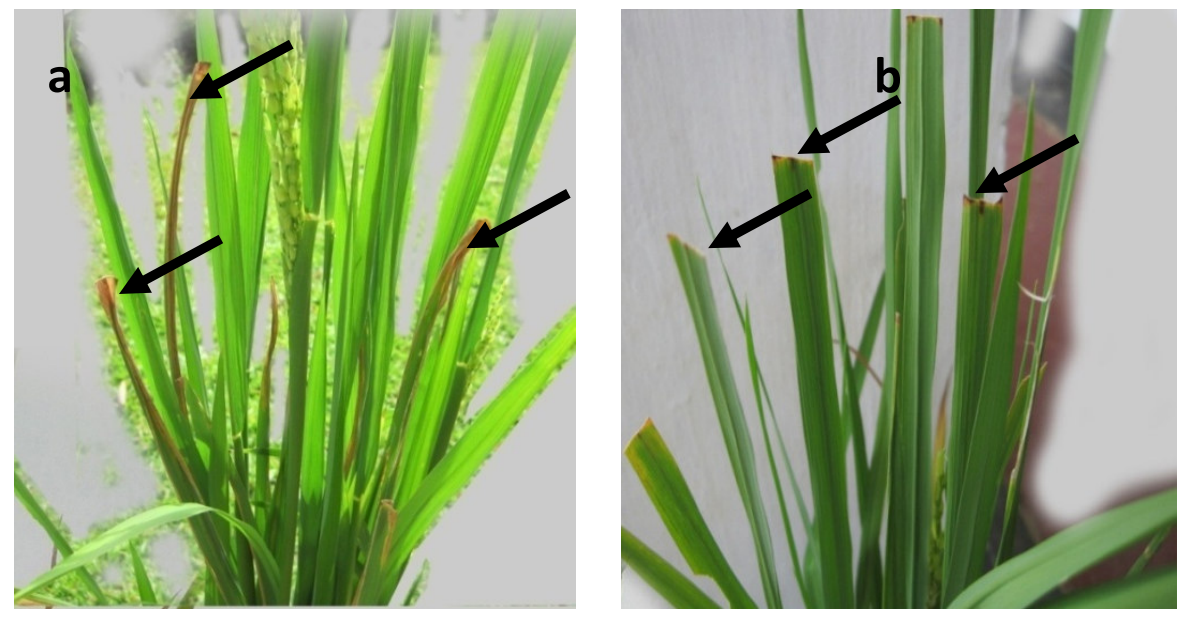

Fig.1. Bacterial leaf blight leaf lesion of (a) Ld 99-12-38 (susceptible parent) and (b) IRBB60 (resistant parent) at 14 days after inoculation with Xanthomonas oryzae pv. oryzae

A paired $t$ - test revealed that the two parents were significantly different $(p=0.001)$ in their response to BLB in all four seasons (Table 01). In all four seasons, IRBB 60 (quantified in terms of BLB disease \%) showed a significantly higher level of resistance $(0.1 \%)$ compared to the Ld 99-12-38 (44\%) against $X$. oryzae pv. oryzae. Hence, the advanced line Ld 99-12-38 was identified as susceptible in all four field trials, and agreeing with the previous reports IRBB 60 was identified as resistant to BLB. The IRBB 60 rice variety is known to carry resistant alleles Xa21, Xa4, xa5, and xa13 (Huang et al., 1997) against BLB, however, the Ld 99-12-38 advance line was not characterized to identify the alleleic haplotype it carried with respect to the above mentioned genes conferring BLB resistance. 
Table 1. Percentage of affected leaf area in $\mathrm{Ld} \mathrm{99-12-38}$ and IRBB 60 rice variety 14 days after innoculation with Xanthomonas oryzae pv. oryzae

\begin{tabular}{|c|c|c|c|c|c|c|}
\hline \multirow[t]{2}{*}{ Parental Line } & \multicolumn{4}{|c|}{ Bacterial leaf blight affected leaf area $\%$} & & \multirow{2}{*}{$\begin{array}{l}\text { disease } \\
\text { response }\end{array}$} \\
\hline & 14 yala & $\begin{array}{l}14 / 15 \\
\text { maha }\end{array}$ & $\begin{array}{c}15 \\
\text { yala }\end{array}$ & $\begin{array}{c}15 / 16 \\
\text { maha }\end{array}$ & average & \\
\hline Ld 99-12-38 & 39.5 & 43.3 & 44.9 & 48.4 & 44.0 & succeptible \\
\hline IRBB 60 & 0.4 & 0.3 & 1.1 & 00.4 & 0.5 & resistant \\
\hline
\end{tabular}

Backcrossing is a well-known and long established breeding scheme, where a desired character is introgressed from a donor parent into the genomic background of a recurrent parent. Hence, the main purpose of backcrossing is to introduce the desired character while restoring the elite donor's genetic background in the resultant progeny. With the assistance of MAS backcrossing process will accelerate the selection of desired plants in early generations. This is beneficial in rice breeding programs because it will reduce the number of unnecessary phenotypes from the population, and target only the desired in consecutive crosses. The reduced number of plants in the trial saves land, labor and input cost. In this investigation backcrossing was performed to introduce the desired resistance alleles of $\mathrm{Xa21}$ and $\mathrm{Xa} 4$ present in IRBB 60 to IRBB $60 / \mathrm{Ld}$ 99-12-38 derived progeny, and restore the genetic background of elite Ld 99-12-38. In each backcrossing the selection was made to pick lines with desirable traits along with low BLB affected leaf area percentage, indicating resistance to BLB.

Here, out of 105 plants in $\mathrm{BC}_{1} \mathrm{~F}_{1}$ inoculated with $X$. oryzae pv. oryzae ,31 plants were categorized as resistant and 21 plants as moderately resistant (Fig.2). Out of these 35 plants carrying the desired attributes of the recipient parent $\mathrm{Ld}$ 99-12-38 were identified, and was advanced up to $\mathrm{BC}_{3} \mathrm{~F}_{2}$ through backcrossing.

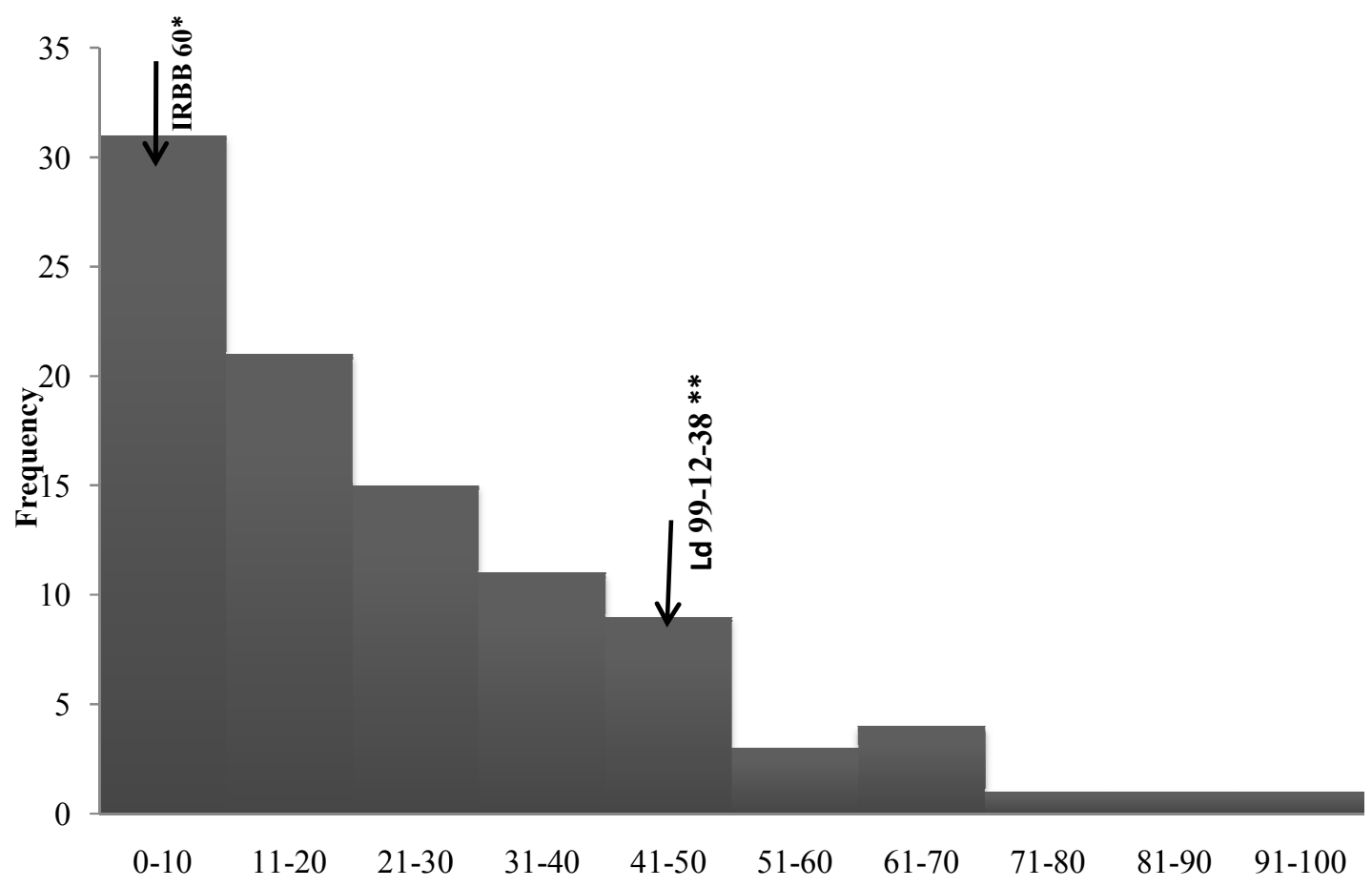

Average lesion length \% 
Fig. 2. Histogram of percentage disease severity in $105 \mathrm{BC}_{1} \mathrm{~F}_{1}$ plants and their parents (IRBB 60 and Ld 99-12-38) at 14 days after inoculation with Xanthomonas oryzae v.oryzae.The BLB scale is given as resistant (1-5\%), moderately resistant $6-12 \%$, moderately susceptible $(13-25 \%)$, susceptible $(25-50 \%)$, and susceptible $(>50 \%)$.

Marker-assisted backcrossing (MAB) with accurate phenotypic selection is the most effective method for a selective transfer or pyramiding of resistance alleles into elite rice varieties, eventually restoring the desired recurrent parent genotype (Joseph et al.2004; Shanti et al. 2010; Singh et al. 2001; Suh et al,2011). It is reported that MAB has been successfully used to introduce a wide spectrum of resistance alleles against Xoo isolates/races in many newly developed rice varieties.

According to the morphological data analysis of the $35 \mathrm{BC}_{3} \mathrm{~F}_{2}$ advanced lines and the resistant parent IRBB 60 (Fig.03), 29 lines were categorized as resistant, and six lines as moderately resistant to BLB.

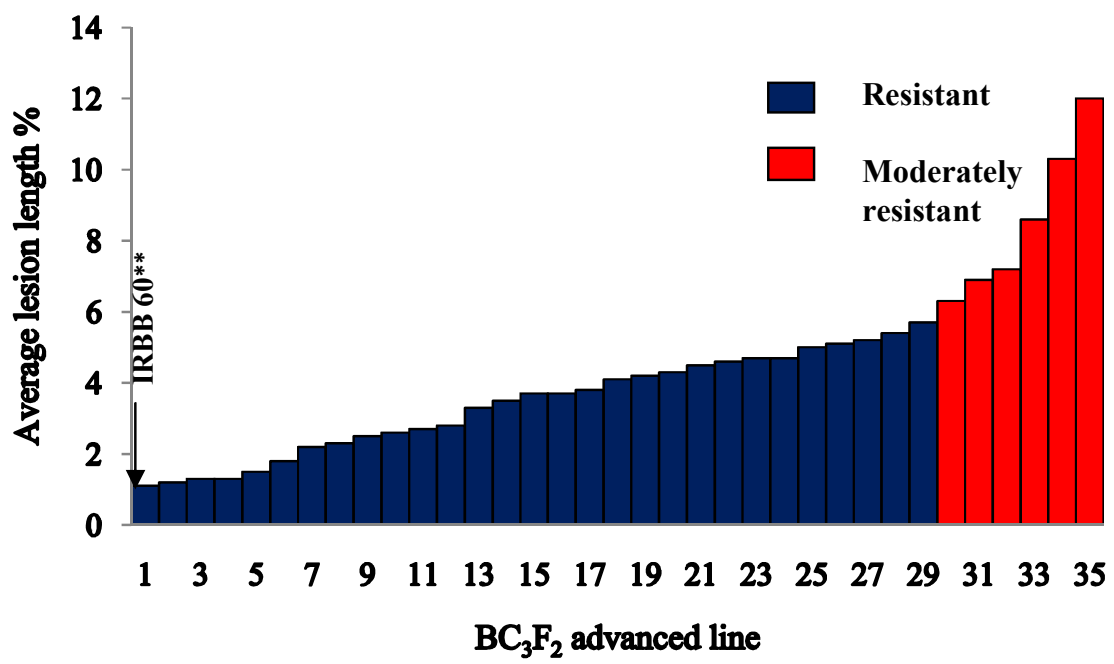

Fig .3. Bacterial leaf blight affected average leaf lesion length \% of $35 \mathrm{BC}_{3} \mathrm{~F}_{2}$ advanced lines

Molecular markers can be used to identify and pyramid favorable alleles in to a selected genetic background (Jena and Mackill, 2008; Lee et al. 2003; Singh et al. 2001; Suh et al., 2009). The molecular level variations of the genes $\mathrm{Xa21}$ and $\mathrm{Xa} 4$ exists as a result of the allelic differences, which gets expressed in terms of resistance/susceptibility to BLB. Out of the two genes Xa21 contributes the largest to BLB resistance. These alleles can be tracked by using molecular markers to identify desired alleles and eliminate the undesired during selection.

According to the results the IRBB 60 variety amplified a fragment for $925 \mathrm{bp}$ for the marker $p$ TA248, confirming the presence of the resistance allele of Xa21 (Table.2; Fig.4a). Further, the Ld 99-12-38 line amplified a fragment of $730 \mathrm{bp}$, which was previously identified as the fragment getting amplified by the susceptible allele (Table.2; Fig.4a). The marker $M P 1+M P 2$ amplified a fragment of 150 bp from the variety IRBB 60 for the Xa4 gene (Table.2; Fig.4b). Further, the Ld 99-12-38 line amplified a fragment of 120 bp, which was previously identified as the fragment getting amplified by the susceptible-allele carrier (Table.2; Fig.4b). Based on the fragments amplified by the linked - markers pTA248 (Xa21) and Mp1+Mp2 (Xa4), it can be confirmed that the variety IRBB 60 and advance breeding line Ld 99-12-38 carried the resistance and susceptibility allele, respectively. 
Table 2. PCR primers, primer sequence, linked genes, expected resistance and susceptible fragment sizes of $p T A 248(\mathrm{Xa21})$ and $\mathrm{MP1}+\mathrm{Mp} 2(\mathrm{Xa} 4)$ primers.

\begin{tabular}{|c|c|c|c|c|}
\hline $\begin{array}{l}\text { Marker/ } \\
\text { Linked } \\
\text { gene }\end{array}$ & Sequence & $\begin{array}{l}\text { Resistant } \\
\text { fragment } \\
\text { size }\end{array}$ & $\begin{array}{l}\text { Suscep } \\
\text { fragment } \\
\text { size } \\
\end{array}$ & Reference \\
\hline pTA248 & F- & $925 \mathrm{bp}$ & $730 \mathrm{bp}$ & Ronald et al.,1992 \\
\hline \multirow[t]{4}{*}{$(X a$ 21) } & 3'AGACGCGGAAGGGTGGTTCCCGGA5 & & & Huang et al., 1997 \\
\hline & & & & Sudarman et \\
\hline & R- & & & al.,2008 \\
\hline & $\begin{array}{l}\text { 3'AGACGCGGTAATCGAAAGATGAAA } \\
5 \text {, }\end{array}$ & & & \\
\hline$M P 1+M P 2$ & F- 3'ATCGATCGATCTTCACGAGG5' & $150 \mathrm{bp}$ & $120 \mathrm{bp}$ & Sun et al.,2003 \\
\hline$(X a 4)$ & R- 3’TGCTATAAAAGGCATTCGG5’' & & & \\
\hline
\end{tabular}

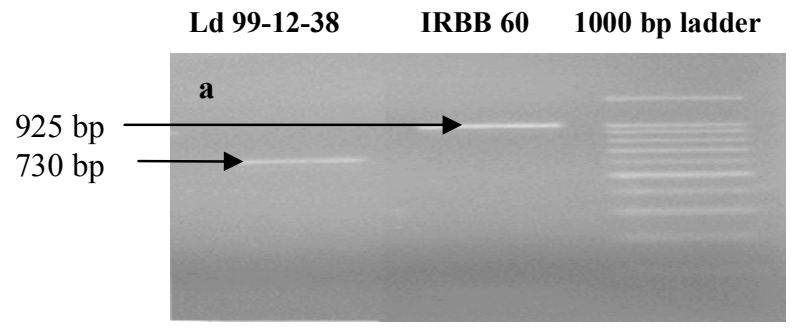

\section{Ld 99-12-38 IRBB $60 \quad 500$ bp ladder}

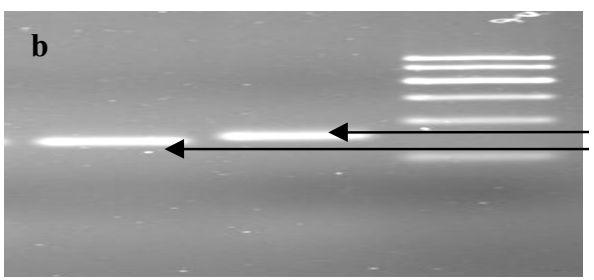

Fig.4. Amplified fragments of (a) Ld 99-12-38 and IRBB 60 for marker pTA248 (Xa21), and (b) Ld 99-12-38 and IRBB 60 for marker Mp1+Mp2 (Xa4).

When the thirty five $\mathrm{BC}_{3} \mathrm{~F}_{2}$ lines derived from a cross between Ld 99-12-38 / IRBB 60 were tested with the BLB resistance gene (Xa21 and Xa4) linked molecular markers $p T A 248$ and $M P 1+M P 2$ it was confirmed that each line at least carried one of the resistance alleles from either Xa21 or Xa4 (Fig. 5a;5b;Table. 3)

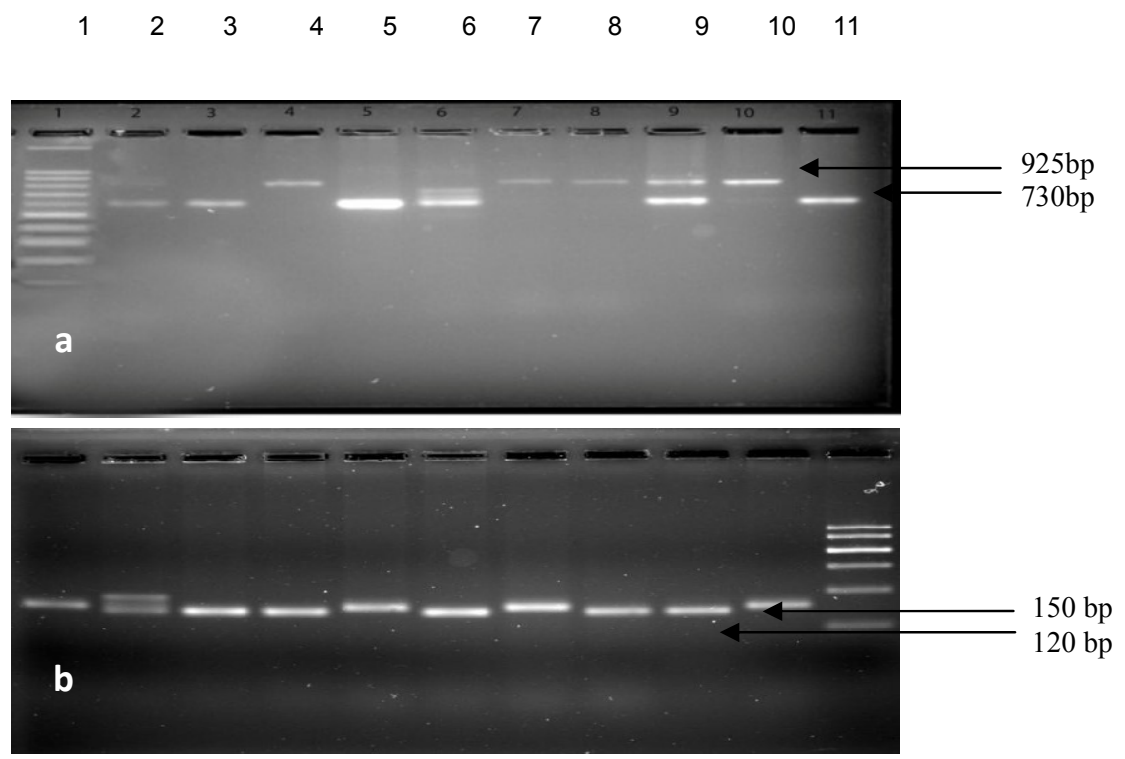


Fig. 05. (a). Amplified fragments of parental lines Ld 99-12-38 and IRBB 60 with $\mathrm{BC}_{3} \mathrm{~F}_{2}$ advanced lines for marker $p T A 248$ (Xa21) and (b) Amplified fragments of parental lines and $\mathrm{BC}_{3} \mathrm{~F}_{2}$ progenies for marker $M P 1+M P 2$ (Xa4)

Out of the tested 35 lines eight lines identified as resistant in the phenotypic trial were confirmed to carry the resistance alleles of both Xa21 and Xa4 genes (Table 3). Twenty one progeny carried only the resistant allele for $\mathrm{Xa4}$, among which was a combination of resistant and moderately resistant. A paired $t$ test revealed that there is a significant difference in the resistance level exerted by progeny carrying resistance alleles of two genes than with one $(p=0.0064)$. Among the tested line none carried only Xa21 resistance allele. In addition, six progeny were heterozygote for $\mathrm{Xa} 4$ locus, and one progeny line was heterozygous at both loci, and these heterozygotic progeny were found to be resistant and hence, has an importance as a genetic resource for further studies.

Table 3 Molecular screening of $B L B$ resistance in $\mathrm{BC}_{3} \mathrm{~F}_{2}$ rice progenies with Parental lines for markers pTA248 (Xa21) and MP1+MP2 (Xa4)

\begin{tabular}{|c|c|c|c|c|c|c|}
\hline \multirow[t]{2}{*}{$\mathrm{BC}_{3} \mathrm{~F}_{2}$ progenies } & \multicolumn{2}{|c|}{ Xa21(pTA248) } & \multicolumn{2}{|c|}{$X a 4(M P 1+M P 2)$} & \multicolumn{2}{|c|}{ Allele } \\
\hline & 925 bp & 730 bp & $150 \mathrm{bp}$ & 120 bp & $X a 21$ & $X a 4$ \\
\hline Ld 99-12-38 & - & + & - & + & $\mathrm{S}$ & $\mathrm{S}$ \\
\hline IRBB60 & + & & + & - & $\mathrm{R}$ & $\mathrm{R}$ \\
\hline $10 \mathrm{R}$ & + & - & + & - & $\mathrm{R}$ & $\mathrm{R}$ \\
\hline 93MR2 & + & - & + & - & $\mathrm{R}$ & $\mathrm{R}$ \\
\hline $100 \mathrm{MR}$ & + & - & + & - & $\mathrm{R}$ & $\mathrm{R}$ \\
\hline $59 \mathrm{MR}$ & + & - & + & - & $\mathrm{R}$ & $\mathrm{R}$ \\
\hline $63 \mathrm{MR}$ & + & - & + & - & $\mathrm{R}$ & $\mathrm{R}$ \\
\hline 93MR1 & + & - & + & - & $\mathrm{R}$ & $\mathrm{R}$ \\
\hline Fiii & + & - & + & - & $\mathrm{R}$ & $\mathrm{R}$ \\
\hline $101 \mathrm{R}$ & + & - & + & - & $\mathrm{R}$ & $\mathrm{R}$ \\
\hline $\mathrm{C}$ & - & - & + & - & - & $\mathrm{R}$ \\
\hline I & + & + & + & + & - & $\mathrm{R}$ \\
\hline 9iii & - & - & + & - & - & $\mathrm{R}$ \\
\hline 3 & - & - & + & - & - & $\mathrm{R}$ \\
\hline 6 & - & - & + & - & - & $\mathrm{R}$ \\
\hline $\mathrm{H}$ & - & - & + & - & - & $\mathrm{R}$ \\
\hline 97R & - & - & + & - & - & $\mathrm{R}$ \\
\hline 8Rii & - & - & + & - & - & $\mathrm{R}$ \\
\hline $72 \mathrm{R}$ & - & - & + & - & - & $\mathrm{R}$ \\
\hline $8 \mathrm{R}$ & - & - & + & - & - & $\mathrm{R}$ \\
\hline 94MR & - & - & + & - & - & $\mathrm{R}$ \\
\hline 9ii & - & - & + & + & - & $\mathrm{R}$ \\
\hline 54MR & - & - & + & - & - & $\mathrm{R}$ \\
\hline 92MR & - & - & + & - & - & $\mathrm{R}$ \\
\hline 92MR2 & - & - & + & - & - & $\mathrm{R}$ \\
\hline 55 & - & - & + & - & - & $\mathrm{R}$ \\
\hline 99MR2 & - & - & + & - & - & $\mathrm{R}$ \\
\hline 11 & - & - & + & + & - & $\mathrm{R}$ \\
\hline 18 & - & - & + & + & - & $\mathrm{R}$ \\
\hline 02 & - & - & + & + & - & $\mathrm{R}$ \\
\hline $9 \mathrm{i}$ & - & - & + & + & - & $\mathrm{R}$ \\
\hline $\mathrm{Fi}$ & - & - & - & + & - & MR \\
\hline $89 \mathrm{R}$ & - & - & + & + & - & MR \\
\hline 12 & - & - & + & - & - & MR \\
\hline Fii & - & - & + & - & - & MR \\
\hline 89Ri & - & & + & - & - & MR \\
\hline 8 & - & - & + & - & - & MR \\
\hline
\end{tabular}




\section{R-resistance, MR-moderately resistance, S-susceptible, + fragment present, - fragment absent}

The eight lines carrying the resistance allele for both $\mathrm{Xa21}$ and $\mathrm{Xa} 4$ were re-evaluated for their resistance responses. They were confirmed to carry the resistance alleles for Xa21 and $\mathrm{Xa} 4$ and was categorized as resistant based on the disease response and carried the elite characteristics of Ld 99-12-38. These eight advance breeding lines can be used in future rice breeding programs towards releasing an elite variety with BLB resistance and as a valuable germplasm resource for breeders.

\section{CONCLUSION}

The advance breeding line Ld 99-12-38 was susceptible to $X$. oryzae pv oryzae, while IRBB 60 was resistant. The molecular markers $p T A 248$ and $M p 1+M P 2$ can be successfully used in MAB to pyramid the resistance alleles of $\mathrm{Xa} 21$ and $\mathrm{Xa} 4$ to achieve sustainable resistance. Eight $\mathrm{BC}_{3} \mathrm{~F}_{2}$ lines pyramided with resistance alleles of $\mathrm{Xa} 21$ and $\mathrm{Xa} 4$ were developed, and was made available for future research at the Regional Rice Research and Development Centre, Bombuwela, Sri Lanka.

\section{ACKNOWLEDGEMENT}

The author greatly acknowledges SL-CARP for their financial assistance under NARP project.

\section{REFERENCES}

García-Yzaguirre, A., Carreres,R, (2008).Efficiency of different hybridization methods in single Crosses of rice for pure line breeding. Spanish J. Agriculture. Res. 6. 395-400.

Huang, N., Angeles, E.R., Domingo, J., Magpantay, G., Singh, S., Zhang, Q., Kumaravadivel, N.,Bennett, J., and Khush, G.S.(1997).Pyramiding of bacterial resistance genes in rice: marker aided selection using RFLP and PCR. Theor Appl Genet. 95.313-320.

Hulbert, S.H.,Webb, C.A., Smith, S.M., and Sun, Q. (2001).Resistance gene complexes: Evolution and utilization. Annu. Rev. Phyto pathol. 39.285-312.

Ikeda, R., Khush, G.S., Tabien, R.E. (1990). A new resistance gene for resistance to bacterial blight derived from o. longistaminata. Japanese Journal of Breed (40). 280-281.

Jena, K.K., Mackill, D.J. (2008). Molecular markers and their use in marker-assisted selection in rice. Crop Sci. 48.1266-1276.

Joseph, M., Gopalakrishnan, S., Sharma, R.K., Singh, V.P., Singh, A.K., Singh,N.K.,Mohapatra, T.(2004).Combining bacterial blight resistance and basmati quality characteristics by phenotypic and molecular marker-assisted selection in rice. Mol Breed 13.377-387.

Joshi, R.K., Nayak, S. (2010). Gene pyramiding-A broad spectrum technique for developing durable stress resistance in crops. Biotechnology and Molecular Biology Review, 5. 51-60.

Kauffman, H. E., Reddy, A. P. K.,Shieh, S. P. Y., Merca, S. D. (1973).An improved technique for evaluating resistance of rice varieties to Xanthomonas oryzae.Plant Dis.Rep, 537-541.

Khan, M. A., Naeem, M., \& Iqbal, M. (2014) . Breeding approaches for bacterial leaf blight resistance in rice (Oryza sativa L.), current status and future directions. European Journal of Plant Pathology, 139(1), 27-37.

Khush, G.S., Jena, K.K., (2009). Current status and future prospects for research on blast resistance in rice (Oryza sativa L.). In Advances in genetics, genomics and control of rice blast disease, 1-10. 
Khush, G.S., Bacalangco, E., and Ogawat, T.(1990). A new gene for resistant to bacterial blight from oryza logistiminata .Rice genetic news, 1 7. 121-122.

Mew,T.W., Alvarez, A., Leach, J., Swings, J. (1993). Focus on bacterial blight of rice. Plant Dis.77.5-12.

Mew, T.W., Vera Cruz, C.M., Medalla, E.S,(1992). Changes in race frequency of Xanthomonas campestris pv. oryzae in response to rice cultivars planted in the Philippines. Plant Dis. 76:1029-1032.

Ou, S. H. (1985). Rice Disease. 2d ed, Common wealth Mycological Institute, Kew, England.380.

Petpisit,V., Khush, G.S., Kauffman, H.E. (1977). Inheritance of resistance to bacterial blight in rice. Crop Sci. 17:551-554.

Shanti, M.L., Shenoy, V.V., Devi, G.L., Kumar, V.M., Premalatha, P., Kumar,G.N., Shashidhar, H.E.,Zehr, U.B., Freeman, W.H. (2010).Marker-assisted breeding for resistance to bacterial leaf blight in popular cultivars and parental lines of hybrid rice. J. Plant Pathol. 92(2):495-501.

Singh S, Sidhu JS, Huang N, Vikal Y, Li Z, Brar DS, Dhaliwal HS, Khush GS(2001).Pyramidingthree bacterial blight resistance genes (xa5, xa13 and Xa21) using marker-assisted selection into indica rice cultivar PR106.

IRRI, 2014., Standard Evaluation System for Rice. INGER Genetic Resources Center, International Rice Research Institute, P.O. Box 933, 1099 Manila, Philippines.

Suh, J.P., Yang, S.J., Jeung, J.U., Pamplona, A., Kim, J.J., Lee, J.H.,Hong,H.C., Yang,C.I., Kim,Y.G.,Jena, K.K. (2011).Development of elite breeding lines conferring Bph18 gene-derived resistance to brown plant hopper (BPH) by marker-assisted selection and genome-wide background analysis in japonica rice (Oryza sativa L.). Field Crops Res.120:215-222.

Suh, J.P., Noh, T.H., Kim, K.Y., Kim, J.J., Kim, Y.G., Jena, K.K, (2009). Expression levels of three bacterial blight resistance genes against K3a race of Korea by molecular and phenotype analysis in japonica rice $(O$. sativa L.). J Crop Sci Biotechnol 12:103-108.

Sundaram RM, Vishnupriya MR, Biradar SK, Laha GS, Reddy GA, Rani NS, Sharma NP, Sonti RV (2008) Marker assisted introgression of bacterial blight resistance in Samba Mahsuri, an elite indica rice variety. Euphytica 160:411-422.

Sun, X., Yang, Z., Wang, S., and Zhang, Q. (2003).Identification of a $47 \mathrm{~kb}$ DNA fragment containing Xa4, a locus for bacterial blight resistance in rice. Theor Appl Genet, 106, 683-687.

Srinivasan, B., and Gnanamanickam, S. (2005). Identification of a new sourceof resistance in wild rice, Oryza rufipogon to bacterial blight of rice caused by Indian strains of Xanthomonas oryzae pv. oryzae. Curr. Sci. 88, 1229-1231.

Wasala,S.K.,Ubesekara,N.M.,Gunasekara,P.S.(2015). Screening of rice germplasm for response to drought at reproductive stage under drought stress conditions, ASDA -2015, 47-50. 